\title{
Human Rights Before the Impact of Industrial Revolution 4.0: Opportunity and Challenges
}

\author{
Dr. Nguyen Thanh Giang ${ }^{(1)}$ and Dr. Nguyen Minh Tri ${ }^{(2 *)}$ \\ ${ }^{(1)}$ Ho Chi Minh City University of Economics and Finance (UEF), Ho Chi Minh City, Vietnam \\ (2) Ho Chi Minh City University of Technology (HUTECH), Ho Chi Minh City, Vietnam \\ *Correspondence author: Nguyen Minh Tri, E-mail: nm.tri@ hutech.edu.vn
}

Article History: Received: 10 November 2020; Revised 12 January 2021 Accepted: 27 January 2021; Published online: 5 April 2021

\begin{abstract}
Human rights are a noble, humane value and a historical product popularity. Human rights are associated with historical traditions, political regimes, the level of development of each ethnic nation. Nowadays, especially in the context of the industrial revolution 4.0, the issue of human rights has become a common concern of the international community, one of the indispensable factors in major planning. Books, laws and foreign relations of each country. In Vietnam, ensuring human rights is a consistent policy in the development strategy, taking people as the goal and driving force of development. Along with the growing and deeper integration of Vietnam, policies to promote and guarantee human rights have been paid more attention to the whole political system. Industrial Revolution 4.0 has had a profound impact on all areas of socio-economic life, including human rights. To promote opportunities and minimize negative impacts, countries need to evaluate the impact of this revolution comprehensively, including the impact on human rights.
\end{abstract}

Keywords: Industrial revolution 4.0, human rights, opportunities, challenges, Vietnam

\section{Introduction}

The industrial revolution 4.0 is going strong around the globe, no one can yet predict how the world will change, because the scale, scope and complexity are extremely large, requiring countries to be more proactive in the strong impacts of smart industry and modern technology. Industrial Revolution 4.0 is developing at an exponential rate, in which many of the contents of this revolution are not fully envisioned, at the same time posing many problems affecting all fields, especially. For upholding human rights. In the early years of the twenty-first century, Vietnam initially took advantage of the achievements of the industrial revolution 4.0, actively contributing to ensuring human rights recognized by the world community, but it is also putting poses many challenges to ensuring human rights in the context of the industrial revolution 4.0. The issue needs to comprehensively identify the opportunities and challenges facing the strong impact of the 4.0 revolution on human rights in Vietnam today.

\section{Research Questions}

Question 1: What are the opportunities and challenges for ensuring human rights in the context of the industrial revolution 4.0 in the world in general and Vietnam in particular?

Question 1: What should be done to ensure human rights before the impact of the industrial revolution 4.0 in Vietnam? 


\section{Literature Review}

Research on human rights. Human rights is a theme that is concerned by a large number of scientists, researching, discussing with many different aspects and angles. Depending on the nature, objectives, goals, scope of research and the appropriate angle, the content of this theme has many different interpretations.

Important international human rights documents such as: Declaration of Independence (United States of America 1776); Declaration on Human Rights and Civil Rights (French Republic of 1789); Universal Declaration of Human Rights (United Nations December 10, 1948); Declaration on the Rights and Freedom of People and Citizens (Russian Federation 11/22/1991); Final Declaration of the Asian Human Rights Conference (Bangkok April 17, 1993); Vienna Declaration and Agenda of Action (World Conference on Human Rights adopted on June 25, 1993 in Vienna, Austria). These are important international documents, the result of the struggles of peaceful and progressive forces, of colonial and dependent countries to regain fundamental human rights. These documents are also useful and reliable references to human rights research (Pham \& Hoang, 1995). In addition, there are also international human rights documents such as: Charter of the United Nations (June 26, 1945); Universal Declaration of Human Rights (December 10, 1948); International Covenant on Civil and Political Rights (December 16, 1966); International Covenant on Economic, Social and Cultural Rights (December 16, 1966); International Covenant on the Rights of the Child (November 20, 1989), etc. These are the Declarations and Conventions that Vietnam is a signatory to. These documents help us to better understand the international community's conception of human rights and legal obligations arising from international documents to which Vietnam is a signatory (Pham, 1998).

Research on human rights is also the object of research in many disciplines such as: law, philosophy, sociology, politics, anthropology, culture, and history... With a multidimensional approach, Multi-disciplinary, we are deeply and comprehensively aware of the value of human rights, creating a broader and more democratic environment for human rights research, effectively promoting the development of children. People (Vinh, 2009), (Vinh, 2010). The Constitution of the Socialist Republic of Vietnam 2013 recognizes, respects, protects and guarantees human rights, political, civil, economic, cultural and social rights that are reflected in the Chapter II, from articles 14 to 49 of the Constitution. (National Assembly, 2015).

In general, this group of studies has provided a multi-dimensional, interdisciplinary, traditional and modern perspective, and all unify human rights as fundamental, sacred, inviolable rights.

Research on industrial revolution 4.0. According to Dinh Cong Tuan in The project of EU social security system and lessons for Vietnam, has analyzed a systematic overview of the settlement of the European workforce in general and some typical countries in the process of labor policy reform in the model. "Social market" of Germany, model of "free market" of England; Swedish model of "democratic society" (Tuan, 2010).

The work of Klaus Schwab, The Fourth Industrial Revolution. In the book, the author presents contents such as: revolution the fourth industrial network, its emergence and its profound changes; and the impacts of Industrial Revolution 4.0 on all areas of social life, especially for the world labor market (Klaus, 2018). 
Industrial Revolution 4.0 - Problems posed for socio-economic development and international integration of Vietnam by Tran Thi Van Hoa, presented the most fundamental issues about the birth history of the industrial revolutions; industrial trends of the Industrial Revolution 4.0; opportunities, challenges and requirements of the Industrial Revolution 4.0 for socio-economic development in general as well as for the labor market in Vietnam. From the analysis of the impact of the Industrial Revolution 4.0, the author has given directions and solutions to build and develop the capacity to innovate and think creatively to take advantage of opportunities and overcome the challenges of Industrial Revolution 4.0 in Vietnam in the coming time (Hoa, 2017).

The Fourth Industrial Revolution - The Revolution of Convergence and Savings by Phan Xuan Dung. The work has summarized the most basic features of the fourth wave of industrial revolution taking place and attracted the special attention of the masses; the nature and impact of the fourth industrial revolution on the world labor market, security and defense. In anticipation of some of the effects of the Fourth Industrial Revolution, countries around the world have come up with breakthrough policies to take advantage of the opportunities and overcome the challenges brought by it (Dung, 2018).

Ensuring human rights before the impact of the industrial revolution 4.0, the study said: "Technology has the power to free us from drudgery or to decimate livelihoods, and the choices that governments and companies make will often determine the difference" (Phil \& Christen, 2018).

\section{Research Method}

Human rights is one of the three main pillars of the United Nations, beside peace - security and development. Human rights are also a major theme in international relations and a central focus in development policy making in countries around the world.

Since its inception (in 1945) and especially over the past two decades, the United Nations has always welcomed all initiatives aimed at bringing standards of human rights (as recognized in basic international documents) become a global reality. One such initiative is to apply a human rights-based approach in development policy making. In 1997, when initiating the program of reform of the organization and activities of the United Nations, the SecretaryGeneral of the United Nations officially called for the inclusion of human rights in all activities of the United Nations. In response to the Secretary-General of the United Nations, organizations under the United Nations began to incorporate a human rights-based approach into their practice from the late 1990s to now on. Since that time, many countries around the world have also promoted the application of a human rights-based approach, and considered human rights as the central focus in the planning and implementation of national development policies.

Theoretically, the viewpoint is taken by the United Nations (through the Office of the United Nations High Commissioner on human rights) on a Human Rights-Based Approach (Human Rights-Based Approach) HRBA (abbreviated as HRBA) is considered mainstream, relatively comprehensive and often widely cited. Accordingly, the human rights-based approach is understood as: “... a conceptual framework for the human development process based on international human rights standards and is implemented towards the goal of promoting and protecting human rights "(Office of the United Nations High Commissioner for Human Rights, 2006: 17).

The above concept shows that the human rights-based approach aims to ensure specific human rights with a balance in two factors: Human rights content and the way of implementing 
human rights. This means that the human rights-based approach is not only concerned with achieving set goals, but also focusing on the processes and ways of choosing to achieve those goals.

The most important meaning of applying a human rights-based approach to development policy is focusing on the interests of vulnerable groups in society and especially those who are the group is at risk of being marginalized. Because, they are in a disadvantaged position or in other words are weak in many aspects such as economy, culture, society and are more difficult than other social groups to access and enjoy achievements brought by development policies of the state. Therefore, in planning and implementing development policies, it is necessary to increase understanding of state agencies about the relationships between rights, obligations and responsibilities for the development objectives and human rights. Focusing on human rights also means making the activities of the state more sustainable and lasting because in terms of the nature of the problem, when the rights and interests of the people are realized. It is also the time for the state to achieve the goals of its management activities, ensuring the fulfillment of national responsibility for international human rights commitments.

The human rights-based approach in planning and implementing policies and development programs is an approach that affirms the inherent rights, interests and freedoms of the rights holders, and at the same time indicate the respective obligations and legal responsibilities of the duty bearers. Rights holders are individuals, citizens, vulnerable social groups in society, while duty bearers are the state, cadres, organizations, corporations, enterprises, etc. The subject is obliged to respect, ensure and enforce the human rights of the rights holders.

The relationship between the beneficiary and the obligor can only really be effective when the application of the human rights-based approach in development policy making must be based on the following principles: i) Legality in decision making; (ii) Transparency in implementation of programs, plans and policies; (iii) Responsibility of the obligor; (iv) Empower vulnerable social groups, marginalized groups; (v) Ensure the participation of rights holders in the process of planning and implementing policies; (vi) Equality, no discrimination.

More specifically, the application of a human rights-based approach in the process of planning and implementing development policies must present basic contents such as:

First, use fundamental human rights standards and principles in the development, implementation, and performance evaluation of development programs and projects.

Second, analyzing and evaluating the capacity of related entities, improving the capacity of the right holder and the responsibility of the obligee to exercise the right.

Third, clarifying the relationship between the right holder and the obligee who is obliged to exercise the right. A rights-based approach requires a clear definition of the roles of the parties and emphasizes the responsibility of the party to exercise the right in an open, transparent and non-discriminatory manner.

Fourth, to pay attention to vulnerable groups, especially those that are vulnerable to being excluded from the development process when they want to achieve results of programs, projects and policies.

Currently, there are many different approaches to policy making and implementation. Besides human rights-based approaches, there are other approaches such as Charity Approach (CA), Needs Approach (NA), Innovative Approach, Positive Approach. Each approach has its own advantages and disadvantages. Compared with other approaches, the human rights-based approach has many advantages, contributing to a highly effective policy making and implementation process in practice. These advantages can be clearly seen in the following comparison table (The Danish Institute for Human Rights, 2007: 10): 
From the above comparison table, the following comments can be drawn:

First, if the need-driven / need-based approach emphasizes social needs, focuses on considering the needs and requirements, thereby proposing solutions in the direction of providing benefits to meet requirements, the human rights-based approach is people-centered to consider and solve problems. Therefore, the human rights-based approach is an effective approach in promoting the development of the relationship between human rights and development (4).

Second, the human rights-based approach is more robust than the need-based approach and the philanthropy / philanthropic approach.

Third, the right-based approach satisfies basic human rights, ensuring stable foundations for human development, thus being ethical, humane, fair and social.

Fourth, the human rights-based approach resolves the relationship between rights-holders and duty-bearers in a frank, practical and reasonable manner.

At the same time, the article is based on the Vietnamese government's views on the promotion of human rights in the socio-economic process. The method used in this research is qualitative analysis and explanatory research. The analysis process was carried out by using historical information and with historical and dialectical materialism methods.

\section{Results and Discussion}

\section{Industrial Revolution 4.0 and impact on human rights}

Karl Marx once judged: The difference among economic eras is not what it produces but how it produces, and what labor documents. Based on this, he determined that the mortar that built rice with water was the era of feudal society, the steam engine was the period of capitalism. Steam engines reflected the results of the Industrial Revolution 1.0 (from 1784). Industrial Revolution 2.0 (from 1870) taking iron and steel as a criterion has brought civilized life, productivity increased many times compared to before. Industrial Revolution 3.0 (since 1969) with the criterion is that computers, internet and eco-engineering have brought industrial society to information society and enriched the way of receiving human information, providing a fast and cheap communication tool between enterprises or within enterprises, between production and business units and consumers... has become an important channel for people to conduct economic activities and how to enjoy.

Entering the early years of the 21 st century, the term Industrial Revolution 4.0 or the fourth industrial revolution has been mentioned a lot on media and social networks. The term "Industrial Revolution 4.0" was first mentioned at the Technology Exhibition Fair Hannover (Germany) and after officially being included in the High-Tech Strategic Action Plan adopted by Germany in 2012; officially recognized the concept and content at the 46th World Economic Forum (WEF), January 20, 2016. Klaus Schwab said: "The fourth industrial revolution formed on the foundation of the digital revolution and incorporates many technologies is driving an unprecedented rapid transformation of the model in economic, corporate, social and personal aspects. It not only changes what we are doing, our way of doing things, but also who we are in the job" (Klaus, 2018).

On May 4, 2017, Prime Minister Nguyen Xuan Phuc signed Directive 16/CT-TTg on strengthening the capacity to access the Industry 4.0, stating: "Industry 4.0 with the development trend based on the highly integrated platform of the digital - physical - biological connection system with the breakthrough of the Internet of Things and Artificial Intelligence is fundamentally changing the production of the world" (Prime Minister, 2017). 
Industrial Revolution 4.0 is the combination of technology in the fields of physics, digital technology and biology, creating completely new production possibilities and having a profound impact on economics, politics, and society of the world. Four key features of the Fourth Industrial Revolution can be generalized: Firstly, based on a combination of new sensor technology, big data analytics, cloud computing and internet of things connectivity will drive the development of automation machines and smart production systems Secondly, using 3D printing technology to produce products completely by unifying production lines without the need to assemble auxiliary equipment - this technology also allows people to print new products using non-traditional methods, bypass intermediaries and reduce production costs as much as possible. Thirdly, nanotechnology and new materials create new material structures that are widely applied in almost all fields. Fourthly, artificial intelligence and cybernetics allow people to control remotely from space, time, and interact faster and more accurately.

Currently, Industrial Revolution 4.0 has created both opportunities and challenges for socioeconomic fields in general, ensuring human rights in particular.

Human rights are an inherent dignity that belongs to all. The universal value that countries around the world today recognize is that all individuals have human rights, should be respected and treated equally without any discrimination on gender or language. Language, race, color, nationality, religion, residence, occupation, disability, social status or any other status. Human rights are recognized and protected by law through international treaties, international practices, documents in the international legal system and the laws of each country. The framework of international human rights standards has been formed, recognized by countries, which requires all institutions and organizations in society to be obliged to respect, protect and implement, including even in the context of many changes today.

Industrial Revolution 4.0 brings both opportunities and challenges to the realization of the responsibility to ensure human rights in countries.

In terms of opportunity, the applications of this Industrial Revolution 4.0 are tools for expanding recognition, promotion and protection of human rights. For example, the right to access information is implemented more quickly and fully with the support of the internet, big data, the development of online information systems, social networks... Big data makes it easier to collect and separate data, thereby supporting and monitoring discrimination against vulnerable groups. Information about human rights violations is also shared more quickly, so that governments, NGOs, and other parties responsible for human rights can receive and provide timely support time.

With the development of new technologies, especially technologies related to health, education can help increase service accessibility and improve socio-economic development indicators, thereby increasing ability to enjoy the right to health, education, food rights, entertainment rights, the right to benefit from the development of science and technology. Digital technology also makes the realization of freedom of expression more effective. Media and social networks are increasingly becoming an important channel expressing the freedom of expression and expression of the people in the world. New technology applications also facilitate access to rights for vulnerable groups. For example, technology contributes to increasing accessibility to services and reducing support costs for people with disabilities. People with a disability will have the opportunity to have greater use of modern equipment to assist with their disability. The development of genetic technology also makes the investigation of crime easier, especially crimes against women and children... 
The development of automatic technology helps free up human labor, increases labor productivity, increases income, contributes to investment in human development through education, medical care, and human rights protection in the production process towards sustainable social growth.

Along with the development of technology is the formation of a free employment economy (gig economy) and new business models in the form of self-employment and self-employed. The current freelance job economy will give workers more opportunities to find jobs and increase their income more flexibly, such as through sharing services when using taxi Uber, Grab, or translation. Freelance jobs on technology platforms like Taskrabbit.

In terms of challenges, the new applications of the Industrial Revolution 4.0 also pose a series of new challenges for the promotion and protection of human rights in many fields. The growth and popularity of the internet as well as social media platforms are an important channel to promote the right to access information, to promote human rights education, to realize freedom of expression and expression, but also poses a new challenge to online violence, aggressive agitation, discrimination and violence, and fake news. The easy access to information and personal data has even led to the violation of democratic rights in the political system, such as the use of technology to interfere in elections in some countries last time.

The development of algorithms and artificial intelligence has in many cases gone beyond the legal system's ability to protect the rights of the legal system, such as online privacy, the right to protect data, and personal information. For example, the rapid dissemination and dissemination of information on social networks can lead to an invasion of freedom of private information because once shared, it is difficult to correct or delete when necessary. Currently, many countries around the world are forced to pass laws on personal data protection in the development of technology, with special emphasis on corporate responsibility to protect privacy. and personal information (Phil \& Christen, 2018). Artificial intelligence can be used as a tool to treat illness, but also increases inequality and disparity in society.

The development of automatic technology has helped free up human labor, increased productivity, but also pushed millions of people to face the risk of losing their jobs. Many traditional industries and trades will also disappear quickly. For example, if in 1998, Kodac camera company employed 170,000 people, accounting for $85 \%$ of the photo paper market in the world, recently, this business line is no longer active.The fields of craft jobs will also disappear, replaced by the emergence of new industries and occupations requiring high skilled skills. According to research by the McKinsey Global Institute, it is estimated that by 2030, between 400 and 800 million jobs in the world will be replaced by automation technology (James, M., \& et al, 2017). The birth of "smart factories", in which machines are in-touch and linked together through a system that can visualize the entire production process by itself, make decisions. Gradually replace the previous production lines. The Industrial Revolution 4.0 will also lead to a trend that countries with technological and capital advantages will return to invest in their own countries on the basis of applying "smart factory" technology. Do not invest in countries with labor advantage. This is a big challenge, especially for countries with a large number of low-skilled workers, requiring the country to have a strategic vision to transform thinking about career, partnership. VND, labor relations for employees.

The status of "temporary labor" and "freelance labor" without labor contracts also poses major challenges to ensuring workers' rights, including the right to satisfactory working conditions. the right to collective bargaining and the right to freedom of association; At the same time, the industrial revolution 4.0 has a special impact on the change of labor markets in 
many countries, although it has just started, but it has been disrupting the traditional labor market structure in many countries..At the World Economic Forum held in 2016 in Switzerland, scientists warned that, under the influence of the industrial revolution 4.0, the labor market will be seriously challenged because of the imbalance. between labor supply and demand. The demand for high quality labor will increase, the demand for unskilled and middle and low skilled workers will decline rapidly. The World Economic Forum 2016 predicted that the 4.0 industrial revolution will create about 2 million new jobs in the high-tech and automation industries, but will disappear about 7 million jobs in the industry. The sector uses a lot of unskilled and low-skilled workers (Klaus, 2018: 123).

Industrial Revolution 4.0 especially affects vulnerable groups, such as women, people with disabilities, children, and the elderly. These are groups that need special assistance in accessing and exercising human rights. The advent of digital technologies with online platforms can contribute to promoting gender equality by helping women access information, education and connection with development opportunities, but also increase risk of cyberattack, harassment, and violence. New technologies can provide learning and information opportunities for children, while also creating new risks to children's rights, including the rise of modern slavery, the exploitation of young labor. Violence, online child abuse, trafficking in children and many other violations of children's privacy.

In the context of the strong development of the Industrial Revolution 4.0, the requirement for today's countries is to have a strategic vision and drastic action to seize opportunities and solve challenges. When considering the impact of the Industrial Revolution 4.0, countries need to pay attention to the multifaceted impact, not only of economy, production technology, management model but also social impacts. , legal and human rights.Industrial Revolution 4.0 will give countries the opportunity to develop more prosperous, connect and integrate more quickly and easily, better ensure human rights, and also have to face challenges on labor rights, inequality, and increased vulnerability for different groups of people in society.

Currently, when formulating and implementing development strategies, policies and programs in the context of the impact of the Industrial Revolution 4.0, many countries emphasize human rights impacts. Governments are very concerned and proactive in issuing their own industrial development strategies. For example, with the common goal of security, prosperity and sustainability, on February 12, 2018, Thailand adopted a human rights platform and program to incorporate into the Thailand Strategy 4. 0. This field includes specific contents: Raising awareness about respect for human rights; building a human rights violation tracking system; building a culture based on rights; building a network to monitor the exercise of rights; improve data on violations of rights; amend the law in response to change; raising awareness of state officials on human rights; reducing human rights violations and abuse; building typical human rights models; take measures to implement human rights proposals. The Australian Government has taken many initiatives to implement the Industrial Revolution 4. 0. In 2016, the Prime Minister of Australia set up a special group of the Government on the Industrial Revolution. 4.0 aims to cooperate with the German Government to implement the 4.0 industrial platform in areas, such as architecture, standard construction, SME support, industrial test station 4. 0 , network security systems, jobs, education and training. Australia's National Committee on Human Rights has carried out a major research project on technology and human rights with many consultations and seminars to identify practical problems. ; conduct research and consult with the public on how best to address opportunities and human rights challenges in the context of new technology, develop an appropriate reform road map (Nguyen, 2021). 


\section{Impacts of industrial revolution 4.0 ensures human rights guarantee against impacts in Vietnam}

For Vietnam, people - people are always placed at the center, both the target and the driving force of all policies and actions. Despite many difficulties and challenges, both objective and subjective, in general, the protection and promotion of human rights in Vietnam has achieved many great achievements, trusted and appreciated by the international community. Since the adoption of the 2013 Constitution, the work of legal reform, institutional and policy improvement has been strengthened with more than 100 laws and laws related to human rights being enacted or amended. Additional. Most recently, on November 20, 2019, the National Assembly passed the Labor Code (amended) with many new regulations to better ensure the rights of workers, basically compatible with important international treaties. Of the International Labor Organization (ILO). The results of ensuring human rights in practice are also evidenced through convincing numbers, such as: good implementation of policies for people with meritorious services, social protection, job creation, sustainable poverty reduction. Firm; The rate of participation in social insurance, health insurance and unemployment insurance increased rapidly; The rate of poor households will decrease to less than $3 \%$ in 2020.The fields of ethnic work, religion, care for the elderly, women, children, fitness, sports and information and communication are focused. Essential infrastructure, especially in poor districts, poor communes and ethnic minority areas, has been strengthened. Vietnam's Human Development Index (HDI) has been continuously improved, belonging to the group of countries with high average human development in the world. We have completed many of the Millennium Development Goals ahead of time, which have been recognized as a bright spot in the field of poverty reduction, health care, and education, and are continuing to actively implement the national action plan for development. Sustainability under the United Nations 2030 Agenda.

Currently, in order to take advantage of the opportunities and overcome the challenges of the industrial revolution 4.0, the Vietnamese government has clearly stated the task: "To soon develop an approach and actively participate in the Revolution Industry 4. 0 ". To implement this policy, in March 2017, the content of the Industrial Revolution 4.0 was discussed at the regular Government meeting. On 4-5-2017, the Prime Minister issued Directive No. 16 CTTTg, on strengthening access capacity to the Fourth Industrial Revolution. This Directive identifies challenges, opportunities and offers solutions and tasks for Vietnam to proactively "take a short cut and stay ahead" in the Industrial Revolution 4.0.

Vietnam belongs to the group of countries in the transition period of the Technology Revolution 4.0 with many development opportunities in the fields of production, service, agriculture, banking, and finance.... The development and application of new technological achievements will bring economic growth to Vietnam, contributing directly to improving people's enjoyment of human rights in many fields. For example, the application of digital technology has helped create jobs and jobs for a number of new industries and occupations in Vietnam, such as technology driving, Airbnb rental services, and online businesses... Thus, it contributes positively to ensuring the right to employment and the right to a satisfactory standard of living for the people.Technological breakthroughs will also help create applications in medicine to actively support expanding access to health services and ensuring health rights. The rapid development of printing and online services is a great opportunity to promote and realize the right to access information and freedom of expression in Vietnam. 
At present, however, Vietnam's access to the 4.0 Industrial Revolution is still at an average low level. According to the assessment of the Ministry of Science and Technology published in April 2017, Vietnam's readiness level in approaching the Industrial Revolution 4.0 only reached 4.9 / 10 points. Therefore, Vietnam needs to have policies, policies and programs to approach this Revolution with a long-term vision, taking into account impacts and risks in the fields of economy, society, law and human rights.

Like in other countries, the impact of the Industrial Revolution 4.0 on human rights is quite clear in terms of both human rights legislation and the practical implementation of rights. Some of the challenges on human rights in Vietnam in the context of the Industrial Revolution 4.0 are as follows:

The development of the Internet and social platforms poses many legal challenges to the realization and assurance of human rights in Vietnam. Regarding privacy, a number of new issues require legalization by legal provisions related to the right to protection of personal data, the right to be forgotten on the Internet. Although it is regulated in the 2013 Constitution, Vietnam has yet to pass a separate privacy law to regulate these new legal issues.

In the field of labor, the emergence of the free economy with new business models and industrial relations forms a new workforce that is outside the regulation of the labor law and Law on Social Insurance of Vietnam. The current Vietnamese labor law also does not recognize some new rights that have emerged in the context of the Industrial Revolution 4.0, such as the right to be disconnected

Industrial Revolution 4.0 has been and is directly affecting the guarantee of employment rights in Vietnam. In the coming time, jobs in manufacturing industries, such as garment, footwear, electronics - which are Vietnam's main export and attract foreign direct investment capital - will be strongly influenced by automation technology, smart factory.Job loss is a risk that Vietnamese workers are directly affected when $17 \%$ of the workforce is active in manufacturing industries. Therefore, building policies, retraining programs, and changing careers for this group of workers is an essential requirement.

\section{Some solutions to promote human rights to the impact of the industrial revolution 4. 0}

To overcome the emerging challenges and further promote human rights to the impact of the current industrial revolution 4.0, it is necessary to pay attention to the implementation of the following basic directions:

Firstly, on the basis of the 2013 Constitution, continues to build and improve the law on human rights assurance. This process should note: (i) Institutionalization of human rights established in the 2013 Constitution into clear, transparent, and consistent standards for understanding and implementation. Do not let the right status "hang". Soon to issue unified guidance on methods of restricting rights in accordance with the provisions of Article 14 of the 2013 Constitution; (ii) Building a legal framework on democracy, the rule of law, and social governance for ensuring human rights. For example, building and implementing laws on implementing socialist democracy such as Law on Referendum, Law on Association, Law on Protests, Law on Access to Information... ; institutionalize the organization and operation of the actual socialist rule of law State (organizational mechanism and operation of the National 
Election Council and National Audit, constitutional mechanism.); institutionalize the State's responsibility for national governance (building the law on supervision and criticism of the Fatherland Front, and managing national security.).On that basis, the State of Vietnam has created a legal framework strong enough to guarantee the rights of all people and all social groups in practice.

Second, continue to focus on building and consolidating state institutions in the protection and supervision of the implementation of human rights. Currently, it is necessary to pay attention to consolidating and perfecting the repair mechanism and compensating for the damage caused by the violation of human rights; detection and prevention mechanisms of human rights violations in all areas; mechanism to protect the rights of vulnerable and vulnerable groups.Next, there is a need to promote the establishment of a specialized national human rights body in addition to the legislative, executive, and judiciary. To do so, it is necessary to promote a comprehensive and scientific study of a number of options for forming this agency in accordance with international standards, with the process of building a Socialist Vietnam State of the Law.

Four options to choose : 1) the Inspector of the National Assembly (ombusman) or the Human Rights Council of Congress as a Congressional committee led by the National Assembly Party; 2) Human Rights Committee under the Government; 3) Vietnam Human Rights Protection Association as a social organization of the Vietnam Fatherland Front; 4) National Human Rights Research Institute.

Third, attaching importance to the application of the human rights-based approach in the formulation and implementation of laws, policies, programs and projects for socio-economic development. The use of this method should focus on building measures to improve the capacity of the rights holder and the obligee to exercise the right in each specific field; creating strong changes in ensuring economic, social and cultural rights for the poor, people with disabilities, ethnic minorities, people living with HIV / AIDS...

Fourth, to increase communication and education on human rights. The current central task is to strongly innovate both the content and methods of human rights education for leaders and managers at all levels; Law enforcement officers and university students. Next, it is necessary to firmly institutionalize the introduction of human rights education into political, administrative schools, universities, and schools of mass organizations. Education must aim to raise awareness, respect and compliance with human rights in the management activities of state agencies, civil servants and public employees; social and economic organizations; development programs and policies.

Fifth, continue to promote international cooperation in the field of human rights in order to improve the capacity to build and enforce the law, the capacity to protect and oversee the guarantee of human rights. At present, attention should be paid to improving the quality of Reports in accordance with the Convention's and the United Nations Human Rights Council's mechanisms; be more proactive in strategy in the process of participating in a number of human rights mechanisms and procedures of the United Nations, Southeast Asia (ASEAN), human rights dialogue, and development of national cooperation forms of economic diversity in human rights education. 


\section{Conclusion}

Over the past years, Vietnam has great achievements of historical significance in ensuring human rights. The position and power of our country has grown much stronger; the scale, potentials and competitiveness of the economy have been raised; economic growth is quite good, macro foundation is basically stable; people's lives in all aspects are constantly being improved; trust of the business community and society increased. Achieving the above results, Vietnam has taken advantage of the positives of the industrial revolution 4.0 to develop people to meet socio-economic development requirements. However, the industrial revolution 4.0 also poses many challenges to human development, requiring Vietnam to synchronously implement the above solutions to ensure human rights in the context of the revolution. Industry 4.0, contributing to building society for sustainable development, because of human development.

\section{Acknowledgement}

We would like to express the anonymous research participants for their willingness to have taken part in this study. Additionally, our sincere gratitude should go to other relevant parties who have given comments and supported us during our study. Without their unconditional help and support, we would have never been able to finish this study.

\section{Conflit of interest}

The authors declare that they have no competing interests.

\section{References}

[1]. Dung, P. K. (1998). Human Rights - Important documents. Hanoi: Social Science Information Institute.

[2]. Klaus, S. (2018). Fourth industrial revolution (ministry of foreign affairs and proofreading). Hanoi: National Political.

[3]. National Assembly. (2015). Constitution of the Socialist Republic of Vietnam. Hanoi: National politics.

[4]. Nguyen, T.T.H. (2021). The impact of the Fourth Industrial Revolution on the assurance of human rights. Communist Review. Retrieved from https://tapchicongsan.org.vn/van_hoa_xa_hoi/-/2018/815807/tac-dong-cua-cuoc-cach-mangcong-nghiep-lan-thu-tu-den-bao-dam-quyen-con-nguoi.aspx

[5]. Hoa, T.T.V. (2017). Industrial Revolution 4.0 - Issues for socio-economic development and international integration of Vietnam. Hanoi: National Political.

[6]. Office of the United Nations High Commissioner for Human Rights. (2006). Frequently Asked Questions on a Human Rights-Based Approach to Development Cooperation. New York and Geneva: United Nations, p.17.

[7]. Pham, K.I., \& Hoang, V. H. (1995). Human rights in the modern world. Hanoi: Human Rights Research Center.

[8]. Phil, B., \& Christen, D. (2018). Addressing the potential human rights risks of the "Fourth Industrial Revolution". Retrieved from https://www.openglobalrights.org/addressing-thepotential-human-rights-risks-of-the-fourth-industrial-revolution/

[9]. James, M., \& et al. (2017). "Jobs lost, jobs gained: What the future of work will mean for jobs, skills, and wages". Retrieved from https://www.mckinsey.com/featured-insights/future-ofwork/jobs-lost-jobs-gained-what-the-future-of-work-will-mean-for-jobs-skills-andwages\#part\%203

[10]. Prime Minister. (2017). Directive on strengthening capacity to access the Fourth Industrial Revolution, number 16 / CT-TTg. Hanoi. 
[11]. The Danish Institute for Human Rights. (2007). "Applying a Right-based Approach - An Inspirational Guide for Civic Society", p.10.

[12]. Tri, N. M., \& Hau, D.T. (2020). Impact of industrial revolution 4.0 on education and training in Ho Chi Minh City, Vietnam. Journal of Critical Reviews, 7(12), pp.2708-2713. Retrieved from https://doi.org/10.31838/jcr.07.12.413

[13]. Tri, N. M. (2020). Impact of Economic Growth on Social Security in Vietnam. International Journal of Humanities and Social Science, Vol. 10, No. 3, pp: 66-71. Retrieved from http://dx.doi.org/10.30845/ijhss.v10n3a9.

[14]. Tri, N. M.,., et al.. (2020). Opportunities and challenges in promoting the role of international integration in the process of socio-economic development in Vietnam. European Journal of Social Sciences, Vol 3, No 2, pp.76-85.Retrieved from https://doi.org/10.46827/ejpss.v3i2.796

[15]. Tri, N. M., \& Nhe, D. T. (2020). Impact of Industrial Revolution 4.0 on the Labor Market in Vietnam. Research in World Economy, Vol. 12, No. 1, pp.94-100. Retrieved from https://doi.org/10.5430/rwe.v12n1p94.

[16]. Tuan, D. C. (2010). The project of EU social security system and lessons for Vietnam. Hanoi: National Political.

[17]. Vinh, V. K. (2009). Human rights: Multi-disciplinary and interdisciplinary approach to social sciences. Hanoi: Social science.

[18]. Vinh, V. K. (2010). Human rights: Interdisciplinary and interdisciplinary approach to jurisprudence. Hanoi: Social science. 